\title{
Contact tracing management of the COVID-19 pandemic
}

\author{
COVID-19 pandemisinde filyasyon ve temaslı yönetimi
}

\begin{abstract}
Asiye Çiğdem şimŞEK ${ }^{1}$, Ateş KARA ${ }^{2}$, Fatma Nur BARAN-AKSAKAL ${ }^{3}$, Mehmet GÜLÜM ${ }^{1}$, Bahattin ILTER ${ }^{1}$, Levent ENDER ${ }^{1}$, Yunus Emre BULUT ${ }^{1}$, Hasan GÜL ${ }^{1}$, Hasan IRMAK ${ }^{4}$, Kerime ALTUNAY ${ }^{1}$, Nilüfer TAVUKÇU1', Deniz ÇAKMAK ${ }^{1}$, Ercüment TOSUN'1, Enver Cihangir GÜLEGEN1', Avni AYDOĞMUŞ ${ }^{1}$, Muhittin DEMIRKASIMOĞLU1
\end{abstract}

\section{ABSTRACT}

Objective: The new type of Corona virus (SARS(oV-2) is the most important item on the agenda, currently affecting our world. The number of cases has exceeded millions and the number of dead has exceeded hundreds of thousands. The precautions to be taken by societies and individuals, especially states, will undoubtedly be the most important task at the end of this epidemic. In our study, analyzes the data and consequences regarding COVID-19, making use of worldwide experiences and national statistics. In the report writing process, evidence-based and scientific tables and charts were used. In these times when most citizens have just begun to encounter the word pandemic, this report has been prepared using the data and scientific facts of the Ministry of Health of the Republic of Turkey. In this study, it was aimed to evaluate "contact tracing management" (detection, referral and follow-up) studies for positive cases with COVID-19 test results and their contacts in Ankara.

Methods: With the Laboratory Information Management System (LBYS), Public Health Management System (HSYS), Contact Tracing and Isolation Tracking System (FITAS) and the Family Medicine Information

\section{ÖZET}

Amaç: Pandeminin toplum düzeyindeki etkisi virüsün bulaștırıcılığına, hastalık olușturma yeteneğine, toplumdaki bireylerin bağıșıklık durumuna, bireyler arası temas ve toplumlar arası ulașım özelliklerine, risk faktörlerinin varlığına, sunulan sağlık hizmetlerine ve iklime bağtı olarak değișiklik göstermektedir. COVID-19 pandemisinin başlangıcından itibaren ülkeler kapasiteleri ve mevcut sağlık altyapılarının durumuna göre değișik stratejiler yürütmüștür. Türkiye'de ilk COVID-19 vakası 11 Mart 2020 tarihinde görülmüș ve salgın bașlangıcından itibaren vaka görülen ülkelere karşılıklı uçuşların durdurulması, okulların kapatılması, evden çalıșma olanaklarının sağlanmasına yönelik yasal düzenlemeler, 65 yaș ve üstü ile 20 yaș ve altı kișiler için sokağa çıkma kısıtlması, topluma yönelik süreli sokağa çıkma uygulaması gibi önlemler alınmıștır. Bir yandan sağlık kurum ve kurulușlarının güncellenmiș pandemi hazırlık planları kapsamında yataklı tedavi kurumlarının “pandemi hastanesi” yaklașımı ile ikinci ve üçüncü basamak hizmet sunumu devam ederken bir yandan da birinci basamak sağlık hizmetleri dahilinde salgın kontrolüne yönelik olarak sahada vaka bulma ve temaslı takibi amacıyla "filyasyon çalıșmaları” planlanmış ve

${ }^{1}$ Ankara Provincial Health Directorate, Ankara

${ }^{2}$ Hacettepe University Faculty of Medicine, Ankara

${ }^{3}$ Gazi University Faculty of Medicine, Ankara

${ }^{4}$ T.C. Ministry of Health, General Directorate of Public Health, Ankara

İletişim / Corresponding Author : Asiye Çiğdem ŞiMŞEK

Ankara İ Sağ. Müd., Halk Sağ. Hiz. Bşk, Eski Numune Hast. Yerleşkesi, B Blok Ankara - Türkiye Geliş Tarihi / Received : 19.06 .2020

E-posta / E-mail : cigdemsimsek2000@yahoo.com

Kabul Tarihi / Accepted : 07.09.2020

DOI ID : 10.5505/TurkHijyen.2020.80688

Șimșek AÇ, Kara A, Baran-Aksakal FN, Gülüm M, iltter B, Ender L, Bulut YE, Gül H, Irmak H, Altunay K, Tavukçu N, Çakmak D, Tosun E, Gülegen EC, Aydoğmus A, Demirkasımoğlu M. Contact tracing management of the Covid-19 pandemic. Turk Hij Den Biyol Derg, 2020; 77(3): 269-280 
System (AHBS) prepared by our Ministry, the COVID-19 test results in Ankara were directed towards the "the Our study, which aims to evaluate contact tracing management" (detection, referral and follow-up) studies, is a descriptive study. Within the scope of the research, the studies between March 11, 2020 and May 31, 2020 were examined. In order to use the data in the study, permission was obtained from the General Directorate of Public Health of the Ministry of Health of the Republic of Turkey.dated 06/12/2020 and numbered 119016548.

Results: In Ankara, the number of contacts per case is 4.07 and the number of contact tracing per case is 4.05. With a total of 398 "Field Contact Tracing Teams" consisting of 1 doctor and 2 health care personnel throughout the city, the average of $50 \pm$ standard deviations reached $99.4 \%$ within hours.

Conclusion: The most effective way to prevent the spread of the virus; the epidemic is expected to be brought under control by public health interventions such as mask use, social distance, hand washing, hygiene rules, infection prevention activities such as indoor ventilation and contact management made through "Field Contact Tracing Teams" and Family Medicine providing service across the country with GPS-based mobile application FITAS.

Key Words: COVID-19, COVID-19 pandemic control, contact tracing yürütülmüștür. Ankara ilinde COVID-19 test sonucu pozitif bulunan vakalar ile onların temaslılarına yönelik "filyasyon" (tespit, sevk ve takip) çalıșmalarının değerlendirilmesi amaçlanmıștır.

Yöntem: Sağlık Bakanlığı tarafından hazırlanan Laboratuvar Bilgi Yönetim Sistemi (LBYS), Halk Sağlığı Yönetim Sistemi (HSYS), Filyasyon ve İzolasyon Takip Sistemi (FiTAS) ve Aile Hekimliği Bilgi Sistemi (AHBS) ile Ankara ilinde COVID-19 test sonucu pozitif vakalar ile onların temaslılarına yönelik "temaslı izleme yöetimi" (tespit, sevk ve takip) çalıșmalarını değerlendirmeyi amaçlayan araștırmamız tanımlayıcı bir çalıșmadır. Araștırma kapsamında 11 Mart 2020 ile 31 Mayıs 2020 tarihleri arasındaki çalıșmalar incelenmiștir. Çalıșmanın yapılması ve yapılan çalıșmanın bilimsel dergilerde yayımlanması amacıyla T.C.Sağlık Bakanlığı Halk Sağlığı Genel Müdürlüğünden 12/06/2020 tarihli ve 119016548 sayılı izin alınmıștır.

Bulgular: Ankara'da ilk vakanın konfirme edildiği 13 Mart 2020 ile 31 Mayıs 2020 arasında toplam 190.823 PCR testi yapılmıș ve 7231 pozitif vaka tanımlanmıștır. Pozitiflik oranı \%3.78'dir. Ankara'da vaka bașına ortalama temaslı kiși sayısı 4,07 olup vaka bașına kiși takibi sayısı ise 4,05'tir. İl genelinde 1 doktor ve 2 sağlık personelinden olușan toplam 398 "Filyasyon Ekibi" ile saatte ortalama $50 \pm$ standart sapma \%99.4'e ulașılmıștır.

Sonuç: Virüsün yayılmasını önlemek için en etkili yöntemler olan maske kullanımı, sosyal mesafe, el yıkama, hijyen kuralları, iç mekan ortam havalandırması gibi enfeksiyon önleme çalışmaları ve GPS tabanlı mobil uygulama FITAS ile ülke genelinde hizmet sunan Saha Filyasyon Ekipleri ve Aile Hekimleri aracılığıyla yapılan temaslı yönetimi gibi halk sağlığı müdahaleleriyle salgının kontrol altına alınması beklenmektedir.

Anahtar Kelimeler: COVID-19, COVID-19 pandemi kontrolü, filyasyon 


\section{INTRODUCTION}

The impact of a pandemic at the community level varies depending on the infectiousness of the virus, the ability to cause disease, the immune status of individuals in the society, inter-individual contact and inter-communal transportation characteristics, the presence of risk factors, the health services provided and the climate $(1,2)$.

Since the beginning of COVID-19 Pandemic, countries have carried out different strategies according to their capacities and the status of their existing health infrastructures.

The first observed case of COVID-19 in Turkey was on March 11, 2020 and measures such as halting flights to and from countries where cases had occurred since the beginning of the epidemic, closing schools, legal regulations for the provision of work from home, a curfew for people 65 years old and over as well as those 20 years old and under, and a curfew of a limited timeframe for the general society was taken. An updated pandemic preparation plan for the health institutions, inpatient institutions under the "hospital pandemic" approach was planned and conducted while continuing to provide secondary and tertiary care services (they are also in the field of epidemic control within the primary health care services, case finding, and contact tracing studies: "Contact Tracing Management").

Contact tracing management is a field study aimed at determining the agent and the source of the agent, that is, to reveal the chain of infection. In other words, it is the search for resources. The word contact tracing refers to study done in medicine to find the cause of the first occurrence of the disease, particularly the source of an infectious disease.

As a result of these studies, important information such as whether the danger still exists and whether other people are at risk can be obtained (1-4).

The guidelines for combating infectious diseases on the official website of the Republic of Turkey,
Ministry of Health, General Directorate of Public Health define contact tracing management/field review as: conducting studies to determine the source and the agent, and/or taking protection and control measures, including contacts.

Contact tracing management is the most classic strategy of "controlling the epidemic" in order to fight infectious diseases. It is a field study aimed at determining the source, i.e. the chain of infection, or "number of contacts in the home environment and workplace environment".

The screening of all people who have come into contact with the cases is to determine from who the case has gotten the infection and who the case has further infected (2).

In this study, it was aimed to evaluate "contact tracing management" (detection, referral and followup) studies for positive cases with COVID-19 test results and their contacts in Ankara.

\section{MATERIAL and METHOD}

With the Laboratory Information Management System (LBYS), Public Health Management System (HSYS), the Fillation and Isolation Tracking System (FITAS) and the Family Medicine Information System (AHBS) prepared by our Ministry, the COVID-19 test results in Ankara were directed towards "the Our study, which aims to evaluate contact tracing management" (detection, referral and follow-up) studies, is a descriptive study. Within the scope of the research, the studies between March 11, 2020 and May 31, 2020 were examined. In order to use the data in the study, permission was obtained from the Republic of Turkey General Directorate of Public Health of the Ministry of Health dated 06/12/2020 and numbered 119016548. 


\section{Timeline}

World Health Organization (WHO): There was an announcement on December 31, 2019, by WHO China Country Office. After reporting that there are many unknown cases of pneumonia in Wuhan, Hubei province of China, WHO first announced that the cause of these complaints was a new type of coronavirus (2019-nCoV).

The Public Health Emergency of International Concern (PHEIC) was held in Geneva on January 29-30, 2020 for the second time after meeting on January 23, 2020 for the first time on the issue of 2019-nCoV. It recommended that imported cases are expected in various countries, so all countries should actively carry out surveillance, early detection, isolation and case management, monitor contacts and prevent the spread of 2019-nCoV infection. The general manager of WHO declared this outbreak, the "COVID-19 Pandemic," on March 11, 2020, and "in the past two weeks, the number of cases outside China has increased by thirteen times, and the number of affected countries has tripled. In the coming days and weeks, we expect an increase in the number of cases, the number of deaths and the number of affected countries." After the announcement, the epidemic spread to many countries, especially in the Asian region, and became international, affecting the world (5).

Republic of Turkey: In Turkey, pandemic preparedness and planning has been ongoing since 2004 in order to prepare a national preparedness plan for the influenza pandemic and to increase cooperation between institutions, representatives of the Ministry of Health, academics, related field experts, and other ministry representatives. The national pandemic preparedness plan was completed and published as part of a Prime Ministry circular in 2006 and according to this plan, "Provincial Pandemic Plans" were prepared in all provinces. In light of the experience gained from the Influenza A(H1N1)pdm09 pandemic in 2009, "National Preparedness Plan for Pandemic Influenza" was updated, taking into account the recommendations made by WHO and European Centre for Disease Prevention and control (ECDC). In 2019, a "national pandemic preparedness plan preparation committee" was established and workshops were held with the participation of Ministry of Health representatives, academics, field experts, and other relevant ministry representatives. The final version of the National Preparedness Plan for pandemic Influenza was approved by the president of Turkey and published as "Global Influenza Pandemic Plan” in the Official Gazette dated April 13, 2019 (6).

Initially, on January 10, 2020, the Turkish Ministry of Health established the COVID-19 Science Committee, which includes the academics who are working in public health, infectious diseases, microbiology, virology, internal medicine, pulmonary diseases, and intensive care after the announcement of the first case of COVID-19 on January 7th, 2020. The COVID-19 science board has been meeting at every stage, making necessary decisions, preparing guides, algorithms, posters and brochures, and updating studies following all developments.

Ankara: In Ankara, in accordance with the "Global Flu Outbreak (Pandemic) Circular" and "Pandemic Influenza National Preparation Plan" prepared by the Ministry of Health and approved by the President of Turkey, the "Pandemic Influenza Ankara Preparation Plan" was prepared and presented to the Ankara Provincial Pandemic Coordination Board on July 4, 2019. In order to facilitate following up on the process, the developments in Ankara in this part of the article are presented chronologically (7).

24th January 2020: From a group of 30 people consisting of 28 Chinese tourists, guides and drivers in a hotel in the Kızılcahamam district, which is $70 \mathrm{~km}$ away from the city of Ankara, a person was sent to the Ankara Training and Research Hospital Infectious Diseases Clinic upon the information that a Chinese citizen had a high fever, and an nasopharyngeal swab was taken. The other people in the group were 
examined by 3 doctors and two health personnel in Kızılcahamam District, and they were allowed to go to their country after PCR test result was negative and the person referred to the hospital was negative. 1st February 2020: Turkey sent a plane to Wuhan with 19 staff from January 31, 2020, 42 people (27 Turkish, 6 Azarbaijani, 4 Turkish dual citizen of China, 3 Georgians, 1 Bulgarians and of 1 Albanians) was brought to Turkey and a total of 61 people were followed for 14 days in quarantine at the Ankara Training and Research Hospital Zekai Tahir Burak (ZTB) Quarantine Hospital. The development of symptoms wasn't observed, and they were discharged February 14, 2020 after the test results received on the discharge day were negative.

4th February 2020: A meeting was held regarding the new coronavirus disease with the chief physicians and infection specialists of public, university and private hospitals of Ankara Province, and the current information about measures to be taken was shared.

25th February 2020: As the cases continued to increase in the city of Kum in Iran, since February 19, 2020, our citizens in Tehran were brought back to Turkey as follows: 17 passengers with fever symptoms were isolated each in individual ambulances, and 30 passengers without any symptoms were sent in shared ambulances to Ankara Training Research Hospital ZTB Quarantine Hospital, and the crew of 85 passengers was transported to the Bilkent Clinic Guesthouse. They were followed up in quarantine for 14 days, and they were discharged on March 10th, 2020 due to the absence of symptom development and negative results on the day of discharge.

28th February 2020: Ankara Public Health Coordination Center (APHCC/Turkish abbreviationHASKOM) was established. The center, where doctors and other assistant health personnel serve 24 hours a day, 7 days a week, has been working as a kind of call center to help our citizens, primary care workers, and district health directorates' staffs solve their questions and problems related to the COVID-19 pandemic process. Since its establishment, it has been distributing virocult swab and rapid diagnosis kits to all public, university and private healthcare institutions in coordination and the employees of the Directorate have been providing a nasopharyngeal swab service.

29th February 2020: As of this date, 295 people residing in Ankara until March 10, 2020 came to Esenboğa Airport on different days, health personnel were welcomed, their fever was measured, insulation was provided at home and followed by telephone for 14 days. 15 people who developed symptoms during the telephone follow-up period, especially in the last group, were taken to the hospital by ambulance and were treated with a COVID-19 diagnosis.

13th March 2020: Three days after the first confirmed case of COVID-19, diagnosed on March 11, 2020 in our country, Ankara Provincial Directorate of Health started the epidemic process management because the first confirmed case in Ankara was on March 13, 2020, five days ago.

15th March 2020: The last group coming into the country, were those who were coming from Umrah. A total of 3247 were kept in quarantine in different places, Gölbașı (3,067 persons) and Haymana (180 persons), and were placed under observation in the dormitories of The Credit Dormitories Institution (CDI/Turkish abbreviation-KYK) and their quarantine process was initiated. 373 of them who tested positive for PCR at different times were treated in our hospitals.

As a second center, A "COVID-19 Case and Contact Tracing Management Center" was established within the Public Health Directorate of Ankara Provincial Health Directorate, and 12 doctors and 39 health personnel were assigned.

\section{The Operation of the COVID-19 Case and} Contact Tracing Management Center

The nasopharyngeal swab, taken at health institutions on the suspicion of Covid-19, is considered 
by Polymerase Chain Reaction (PCR), and the results of the evaluation are entered into the laboratory information system. Then, Laboratory Information Management System (LIMS/ Turkish abbreviation-LBYS) deliveres the results to the Public Health Management System (PHMS/ Turkish abbreviation-HSYS).

The employees of the center communicate as soon as possible with the person they see on the HSYS screen as a positive case and exchange information about their health status first, and add it to HSYS by asking about the accuracy of the family contact information they see on the HSYS screen, who they have contact with other than those in the system, and of any workplace contacts. An ambulance is then sent for the patient to go to the hospital and the transfer is carried out immediately.

20th March 2020: The COVID-19 Case and Contact Tracing Management Center is contacted by the "Crisis Coordination Centre" as a third centre to carry out the transfer.

This center is a 24/7 operating center consisting of personnel from the presidencies of the Emergency Medical Services, Public Health Services, Health Services and public hospitals. It does what is necessary to carry out the process of sending all positive cases to the hospital by ambulance if necessary.

\section{Management of Contact Tracing Applications}

Another important task of the Case and Contact Tracing Management Center is to identify the cases and carry out the necessary referral process, and to ensure the organization and coordination of the transportation and follow-up of the District Health Directorates and contact execution as soon as possible.

While determining the contacts, in the week prior to the occurrence of the symptoms, contact persons are identified and their information is entered into HSYS to be followed up for 14 days.

The first follow-up of the contacts, District Health Directorates, are made by visiting "Field Contact Tracing Teams" at their homes and necessary inspection procedures are carried out. In this context, as of May 31, 2020, 6890 "Field Contact Tracing Teams" consisting of doctors, nurses, and other health personnel in a group of 3 people, and 398 involved in "Contact Tracing" in Ankara conduct field contact tracing activities.

With the Contact Tracing and Isolation Tracking System (CTITS/Turkish abbreviation-FITAS) by our ministry, all field contact tracing teams providing services throughout the country are notified using their mobile phones of the contacts closest to their location and are provided to follow up and log in to the system.

The information obtained with FITAS is transferred to the Integrated Systems HSYS and Family Medicine Information System (FMIS//Turkish abbreviationAHBS). The information transferred to AHBS is examined by the family doctor who is registered with the case and the contact person, and every day for 14 days, they are called and information about their health status is received.

If any of the symptoms of the COVID-19 disease are reported by the family doctors in the case followup and Case and Contact Tracing Management Center and sent to the hospital by ambulance under the Coordination of the Crisis Coordination Center.

\section{RESULTS}

Our city, Ankara, is the second largest city and the capital of the Republic of Turkey. It is home to all foreign embassies as the headquarters of the Republic of Turkey. It is located in central Anatolia region. Its population is 5.639.076 and it has a total of 25 districts (Table 1).

InAnkara, a total of 190.823 PCR tests were performed between March 13, 2020 and May 31, 2020, and 7231 were identified as positive cases. The percentage of positivity is $3.78 \%$. In Ankara, the number of contacts per case is 4.07 and the number of contact tracing per case is 4.05 . With a total of 398 "Field Contact Tracing Teams" consisting of 1 doctor and 2 health care personnel throughout the city, the average of $50 \pm$ standard deviations reached $99.4 \%$ within hours (Figure 1). 
Table 1. General information about Turkey and Ankara

\begin{tabular}{|l|c|c|}
\hline Info & Ankara & Turkey \\
\hline Area $\left(\mathrm{km}^{2}\right)$ & 25.632 & 814.578 \\
\hline District Number & 25 & 973 \\
\hline Population of TUIK (2019) & 5.639 .076 & 83.154 .997 \\
\hline Population Growth Rate (thousands) & 10,8 & 14,7 \\
\hline Rough Birth Rate (thousands) & 13,3 & 15,3 \\
\hline Rough death Rate (thousands) & 4,7 & 5,3 \\
\hline
\end{tabular}

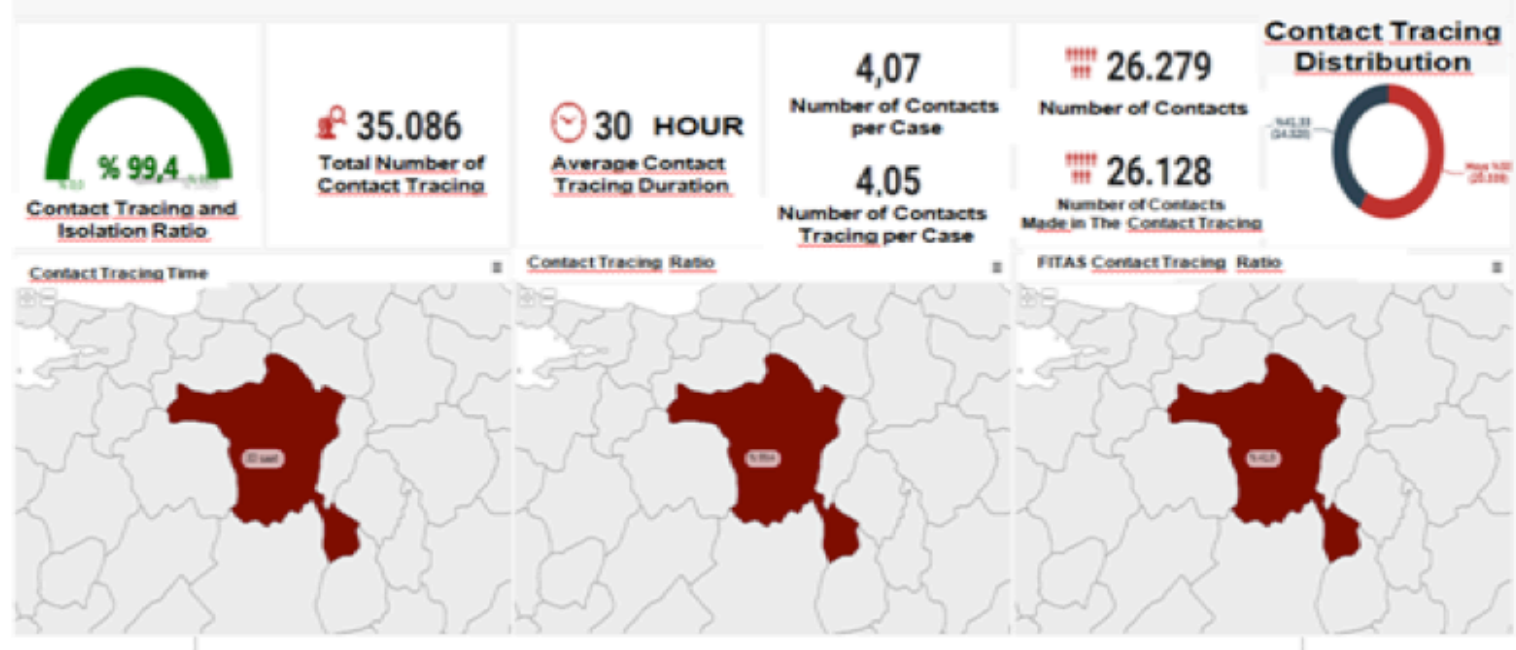

Figure 1. Evaluation of the Field Contact Tracing Teams Work in Ankara, May 31, 2020

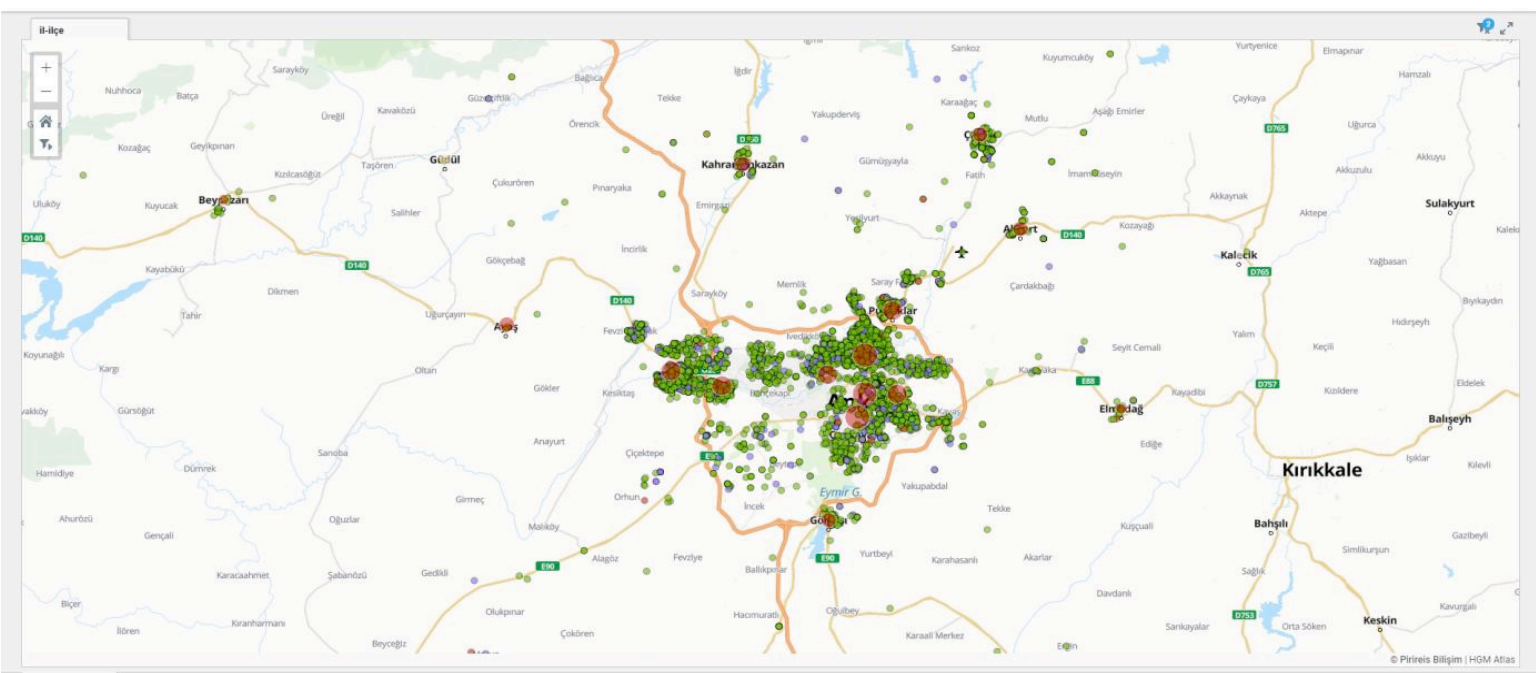

Figure 2. Number of Contacts in Ankara Province by District, May 31, 2020 
According to the districts of Ankara Province, Keçiören, Sincan, Çankaya and Yenimahalle Districts the numbers of cases and contacts are highest in (Figure 2, Table 2).

Table 2. Number of Case Contacts by Districts of Ankara Province, May 31, 2020

\begin{tabular}{|c|c|c|c|c|}
\hline Districts & $\begin{array}{l}\text { Population } \\
\text { (2019) }\end{array}$ & $\begin{array}{c}\text { Contact Isolation } \\
\text { Continues } \\
\text { (FITAS+HSYS) }\end{array}$ & $\begin{array}{l}\text { Contact Isolation } \\
\text { Finished } \\
\text { (FITAS+HSYS) }\end{array}$ & $\begin{array}{l}\text { Contact Total } \\
\text { (FITAS+HSYS) }\end{array}$ \\
\hline Akyurt & 36.123 & 57 & 212 & 269 \\
\hline Altındağ & 389.510 & 570 & 1347 & 1917 \\
\hline Ayaș & 13.900 & 10 & 25 & 35 \\
\hline Bala & 30.280 & 32 & 109 & 141 \\
\hline Beypazarı & 48.371 & 14 & 236 & 250 \\
\hline Çamlıdere & 9.825 & 3 & 5 & 8 \\
\hline Çankaya & 944.609 & 678 & 2484 & 3162 \\
\hline Çubuk & 90.764 & 72 & 532 & 604 \\
\hline Elmadağ & 45.557 & 44 & 242 & 286 \\
\hline Etimesgut & 587.052 & 339 & 2562 & 2901 \\
\hline Evren & 3.097 & 0 & 6 & 6 \\
\hline Gölbaşı & 138.944 & 463 & 98 & 561 \\
\hline Güdül & 8.892 & 0 & 6 & 6 \\
\hline Haymana & 30.930 & 132 & 156 & 288 \\
\hline Kahramankazan & 54.806 & 60 & 382 & 442 \\
\hline Kalecik & 13.234 & 2 & 17 & 19 \\
\hline Keçiören & 939.161 & 747 & 3763 & 4510 \\
\hline Kızılcahamam & 28.350 & 9 & 296 & 305 \\
\hline Mamak & 665.978 & 1420 & 406 & 1826 \\
\hline Nallıhan & 27.579 & 0 & 64 & 64 \\
\hline Polatlı & 125.075 & 270 & 226 & 496 \\
\hline Pursaklar & 150.488 & 211 & 784 & 995 \\
\hline Sincan & 535.637 & 433 & 3487 & 3920 \\
\hline Şereflikoçhisar & 33.821 & 2 & 107 & 109 \\
\hline Yenimahalle & 687.093 & 578 & 2430 & 3008 \\
\hline Total & 5.639 .076 & 6146 & 19.982 & 26.128 \\
\hline
\end{tabular}


45.909 people who came to our city from tracing by the provincial health directorate (Table 3). international and from intercity were in contact

Table 3. Number of international/intercity incoming people monitored by districts of Ankara Province

\begin{tabular}{|c|c|c|c|}
\hline Districts & $\begin{array}{l}\text { Ongoing Follow-up } \\
\text { (International/ } \\
\text { Intercity) }\end{array}$ & $\begin{array}{l}\text { Followed Up } \\
\text { (International/ } \\
\text { Intercity) }\end{array}$ & Total \\
\hline Akyurt & 16 & 77 & 93 \\
\hline Altındağ & 639 & 1355 & 1994 \\
\hline Ayaș & 18 & 28 & 46 \\
\hline Bala & 36 & 95 & 131 \\
\hline Beypazarı & 34 & 93 & 127 \\
\hline Çamlıdere & 0 & 6 & 6 \\
\hline Çankaya & 454 & 16004 & 16458 \\
\hline Çubuk & 79 & 433 & 512 \\
\hline Elmadağ & 79 & 383 & 462 \\
\hline Etimesgut & 407 & 4272 & 4679 \\
\hline Evren & 2 & 26 & 28 \\
\hline Gölbașı & 666 & 2130 & 2796 \\
\hline Güdül & 8 & 12 & 20 \\
\hline Haymana & 39 & 254 & 293 \\
\hline Kahramankazan & 75 & 221 & 296 \\
\hline Kalecik & 47 & 36 & 83 \\
\hline Keçiören & 846 & 4205 & 5051 \\
\hline Kızılcahamam & 61 & 102 & 163 \\
\hline Mamak & 954 & 2255 & 3209 \\
\hline Nallıhan & 21 & 41 & 62 \\
\hline Polatlı & 152 & 464 & 616 \\
\hline Pursaklar & 134 & 578 & 712 \\
\hline Sincan & 763 & 1620 & 2383 \\
\hline Șereflikoçhisar & 24 & 251 & 275 \\
\hline Yenimahalle & 687 & 4727 & 5414 \\
\hline Total & 6241 & 39.668 & 45.909 \\
\hline
\end{tabular}


In Ankara city, between March 13, 2020 and May 31, 2020, a total of 7231 COVID-19 cases with a PCR positive result were detected, and a total of 26.128 contacts belonging to these cases were reached, and a follow-up of 19.982 contacts was completed. Apart from the case contacts, a total of 45.909 people coming from international and from intercity within the scope of the contact tracing were followed up with their contacts, and the follow-up of 39.688 was completed. The follow-up of 53.540 contacts in total has been completed. According to the PCR test results of all the contacts, 2549 new cases were detected, and the overall secondary clinical attack rate was calculated to be $5.04 \%(95 \% \mathrm{Cl})$.

\section{DISCUSSION}

In this study, the contact tracing studies carried out following the first incident of COVID-19 on March 13, 2020 in the capital Ankara are presented. For health care personnel was prepared and website of the Ministry of Health published by the Scientific Committee on COVID-19 on the on guides, algorithms, training materials (banners, brochures), hygiene rules, hand washing, mask use, isolation measures, social distance. The Scientific Committee has issued a number of guidelines on diagnosis, treatment, infection control, quarantine and social distancing, and periodically updates these guidelines.

The review article prepared by Demirbilek et al., one of the first publications on the subject in our country, is very valuable in this regard (8).

In the study of Nussbaumer-Streit B et al., it was stated that quarantine practices are important in reducing the incidence of COVID-19 and mortality from it, and it is important to ensure the effectiveness of quarantine application in combination with other public health measures (9). In the study of Boccia et al., standard hygienic measures, one of the effective public health interventions, were not adopted early in some regions of Italy and are likely to affect the prevalence of infection.

Therefore, the implementation of conditions such as home insulation has probably been difficult (10).
The quarantine of those coming from countries with COVID-19 cases before and after the incident occurred in Turkey and especially in Ankara province is one of the most important measures taken in this regard.In the study of Anelli et al., it was noted that the use of protective equipment by health workers is both essential for disease control and a crucial factor for continuing to provide care to patients (11). Our field contact tracing teams use medical masks, gloves, eye protection and wear protective equipment during home visits as recommended by the WHO (12).

In order to eventually succeed in controlling the outbreak, reducing the reproduction number of COVID-19 to less than one, methods such as contact tracing, quarantine, testing, isolation, social distancing and school closure are critical. In the early stages of the COVID-19 outbreak when imported cases from China and their linked cases were identified, the KCDC actively performed contact tracing, quarantined the contacted persons, and diagnosed and isolated the COVID-19 cases as soon as possible, which was reported to be effective (13).

In the description of Cha V. et al., two months after the first confirmed case, South Korea managed to control the outbreak with protection control studies, such as diagnostic tests, frequent public information, meticulous contact follow-ups, patient surveys, and meticulous contact mapping through GPS-based mobile apps (14). With the GPS-based mobile application FITAS prepared by our Ministry, all Field Contact Tracing Teams providing service across the country are informed by following the closest contacts to their mobile phones and entering it in the system. In this way, case investigation work was carried out without wasting time (15).

The overall secondary attack rate is calculated to be $5.04 \%$ (95\% GA) in our study in Ankara. A remarkable report from Taiwan described the use of contact tracing and virologic PCR testing to assess the transmission dynamics of COVID-19 in the country's initial 100 confirmed cases. Among 2761 close contacts of the 100 cases, confirmed between January 15 and March 18, 2020, Cheng et al report that there were 22 paired-index secondary cases and an overall 
secondary clinical attack rate of $0.7 \%(95 \% \mathrm{Cl}, 0.4 \%$ $1.0 \%)$. The overall secondary clinical attack rate in the present study is much higher than that reported in Taiwan. This may be due to closer contact within our country or the study period coinciding with the peak period of the outbreak in Ankara and in Turkey. Besides, viral shedding studies and epidemiological investigations suggest that in the household, around $40 \%$ of transmission occurs before symptom onset, the live virus is shed for at least 1 week after symptom onset, and there is high spreading in asymptomatic individuals (16-18). Although a report by Salathé et al focuses on the epidemiological aspects of testing, it also states that there are economic and social benefits to a liberal testing strategy. The costs of increased testing, contact tracing, and self-isolation are high in the short term. In the longer term, however, more rapid control will reduce the economic and social costs of social- distancing measures that adversely affect businesses, communities, and individuals (19). Although the exact proportion of household among the contacts is not known in our study, it is likely to be high and this may be one of the contributors to the high attack rate.

Findings show the public health need for accurate and comprehensive contact tracing and testing. Testing only those people who are symptomatic will miss many infections and render contact tracing less effective.

It has been found that asymptomatic people and those with minimal or fewer symptoms early in infection are those most likely to transmit COVID-19. Maintaining social distancing and having people wear face masks to reduce the potential for transmission should support contact tracing activities. Solely isolating patients symptomatic with COVID-19 will fail to control transmission during the infected but asymptomatic stage. So close monitoring and keeping isolation for at least 14 days for all the contacts with or without symptoms is essential (20). Turkey is on the eve of the "reopening" of society like many other countries. It is important to continue sufficient testing and contact tracing in order to control possible outbreaks that may inevitably occur as social restrictions are removed. While containing the infections, and during "reopening," social distancing throughout society and the wearing of face masks should be maintained to the maximum extent possible until there is a vaccine or effective treatment.

\section{CONCLUSION}

After the COVID-19 disease was defined, it was not limited to the region where it was located, and the number of cases gradually increased and turned into a huge pandemic that caused disease and a loss of life affecting the whole world.

Since the time when COVID-19 disease was identified, scientists have been making great efforts to determine the characterization of the new coronavirus and to develop antivirus therapies and vaccines. The most appropriate treatment for patients under observation, diagnosed with COVID-19 is still unknown. Clinical and vaccine studies are continuing rapidly. Nevertheless, the pathogenesis of the virus is still unknown, and new studies are needed (21). Therefore, the most effective way to prevent the spread of the virus; the epidemic is expected to be brought under control by public health interventions such as mask use, social distance, hand washing, hygiene rules, infection prevention activities such as indoor ventilation and contact management made through Field Contact Tracing Teams" and Family Medicine providing service across the country with GPS-based mobile application FITAS.

Although the rapid and sustained responses to control the COVID-19 outbreak could slow its spread, this outbreak could last for a long time with the risk of an unexpected surge again. Case finding and contact tracing will be the key in responding to any possible resurgence. 


\section{REFERENCES}

1. T.C. Sağlık Bakanlığı, Halk Sağlığı Genel Müdürlüğü, COVID-19 (SARS-CoV-2 Enfeksiyonu) Rehberi, 14 Nisan 2020, Ankara.

2. T.C. Sağlık Bakanlığı, Halk Sağlığı Genel Müdürlüğü, Bulașıcı Hastalıklar ile Mücadele Rehberi, 2017, Ankara.

3. Halk Sağlığı Temel Bilgiler, Hacettepe Üniversitesi Yayınları, 2006, Sayfa: 865-87, Ankara.

4. Temel Epidemiyoloji, Sabahat Güven Tezcan, Hipokrat Yayınevi, 2017, Sayfa: 190-209, Ankara.

5. World Health Organization (2020). Coronavirus Disease (COVID-19) events as they happen [online]. Website: https:// www.who.int/emergencies/ diseases/novel-coronavirus-2019/ events-as-theyhappen [accessed 28 April 2020].

6. T.C. Sağlık Bakanlığı, Halk Sağlığı Genel Müdürlüğü, Pandemik İnfluenza Ulusal Hazırlık Planı, 2019, Ankara.

7. Ankara il Sağlık Müdürlüğü, İ Pandemi Planı, 2019, Ankara.

8. Demirbilek Y, Pehlivantürk G, Özgüler Z, , Alp Meșe E. COVID-19 Outbreak control, example of Ministry of Health of Turkey, Turkish Journal of Medical Sciences (2020) 50: 489-94.

9. Nussbaumer-Streit B at all, Quarantine alone or in combination with other public healthmeasures to control COVID-19: a rapid review, Cochrane Database of Systematic Reviews.

10. Boccia S., Ricciardi W., loannidis J., What other countries can learn from italy during the COVID-19 Pandemic, JAMA Intern Med. Published online April 7, 2020. doi:10.1001/jamainternmed.2020.1447.

11. Anelli F. at all. Italian doctors call for protecting healthcare workers and boosting community surveillance during Covid-19 outbreak, BMJ 2020;368:m1254 doi:10.1136/bmj.m1254 (Published 26 March 2020).

12. World Health Organization (WHO), Rational use of personal protective equipment for coronavirus disease (COVID-19): interim guidance, 27 February 2020.
13. Choi JY. Covid-19 in South Korea. Postgrad Med J. 2020 May 4. pii: postgradmedj-2020-137738. doi: 10.1136/postgradmedj-2020-137738. [Epub ahead of print].

14. Cha V. A Timeline of South Korea's response to COVID-19, March 27, 2020. https://www.csis.org/ analysis/timeline-south-koreas-response-covid-19.

15. Hao-Yuan Cheng, MD, MSc, 1 Shu-Wan Jian, DVM, $\mathrm{MPH}, 1$ Ding-Ping Liu, PhD, $1 \mathrm{Ta}-\mathrm{Chou} \mathrm{Ng}, \mathrm{BSc}, 2$ Wan-Ting Huang, MD, 3 and Hsien-Ho Lin, MD, ScD, Contact tracing assessment of COVID-19 transmission dynamics in taiwan and risk at different exposure periods before and after symptom onset, JAMA Intern Med. 2020 May 1 : e202020.

16. Wölfel R, Corman VM, Guggemos W. Virological assessment of hospitalized patients with COVID-2019. Nature. 2020 doi: 10.1038/s41586020-2196-x. published online April 1. [CrossRef] [Google Scholar].

17. He X, Lau EHY, Wu P. Temporal dynamics in viral shedding and transmissibility of COVID-19. Nat Med. 2020 doi: 10.1038/s41591-020-0869-5. published April 15. [CrossRef] [Google Scholar].

18. Ferretti L, Wymant C, Kendall M. Quantifying SARSCoV-2 transmission suggests epidemic control with digital contact tracing. Science. 2020 doi: 10.1126/ science.abb6936. published online March 31. [CrossRef] [Google Scholar].

19. Salathé $M$, Althaus $C$, Neher $R$, Stringhini $S$, Hodcroft E, Fellay J, Zwahlen M, Senti G, Battegay M, Wilder-SmithA, Eckerle I, Egger M, Low N. COVID-19 Epidemic in Switzerland: On the Importance of Testing, Contact Tracing and Isolation. Swiss Med Wkly. 2020;150:w202205, oi:10.4414/smw.2020.20225.

20. Steinbrook R. Contact Tracing, Testing, and Control of COVID-19-Learning From Taiwan JAMA Intern Med. Published online May 1, 2020. doi:10.1001/ jamainternmed.2020.2072, doi: 10.1001/ jamainternmed.2020.2020 [Epub ahead of print].

21. COVID-19 Situational Assessment Report (COVID-19 Pandemi Değerlendirme Raporu), Turkish Academy of Sciences, March 17, 2020. Ankara. 